\title{
Macrophages and mast cells in chronic cholecystitis and "normal" gall bladders
}

\author{
I HUDSON, D HOPWOOD
}

From the Department of Pathology, Ninewells Hospital and Medical School, Dundee, Scotland

SUMMARY An attempt was made to quantify mast cells using toluidine blue and macrophages, with $\alpha-1$-antitrypsin as a marker, from adjacent sections in the mucosa of two groups of gall bladders showing either minimal inflammatory change or established chronic cholecystitis. The results were expressed as cells $/ \mathrm{mm}^{2}$ of mucosa. Alpha-1-antitrypsin showed both macrophages and mast cells, and therefore an estimate of macrophage numbers was obtained by subtraction. Mast cells comprised more than $60 \%$ of the $\alpha$-1-antitrypsin positive cells. There were significantly (p $>0.001$ ) more mast cells and macrophages in minimal inflammatory gall bladder mucosa than in established chronic cholecystitis.

In previous studies we described macrophages containing lipid in the mucosa of gall bladders from patients with both chronic cholecystitis and cholesterolosis and speculated on their possible transport function. ${ }^{12}$ We decided to try to quantitate mucosal macrophages comparing gall bladders with minimal cholecystitis against those with well established chronic cholecystitis, looking for patterns that may elucidate their possible role in the pathophysiology of chronic cholecystitis.

Various techniques are available for showing the presence of macrophages in tissue sections. Histochemically, non-specific esterase and acid phosphatase have been used with frozen sections. ${ }^{34}$ For paraffin sections, various macrophage markers have been used for the immunoperoxidase technique, including lysozyme ${ }^{5}$ and antichymotrypsin. ${ }^{6}$ The most widely used marker at the present time is $\alpha$-1-antitrypsin, ${ }^{7}$ which gives the clearest preparations for quantitation. Mast cells, however, also contain $\alpha$-1-antitrypsin. ${ }^{8}$ The use of toluidine blue on trypsinised sections allows mast cells to be quantified in formalin fixed paraffin sections. ${ }^{9}$ Subtraction of the mast cell count from the total $\alpha$-1-antitrypsin cells in a given area gives an estimate of the number of macrophages.

Accepted for publication 23 April 1986

\section{Material and methods}

Eleven gall bladders were obtained straight from the operating theatre after routine cholecystectomy, opened immediately, and fixed in phosphate buffered formalin (pH 6.9-7.0) for up to 24 hours. Blocks were taken from the body of the gall bladder and embedded in paraffin wax. Sections stained with haematoxylin and eosin were examined. Six specimens that showed minimal inflammatory change, classified as "normal" and five that showed the features of chronic cholecystitis were used in the study. Sections $(5 \mu \mathrm{m})$ were transferred to slides coated with poly-1lysine. For quantitative purposes six sections per gall bladder were taken, comprising two serial sections from three different levels in the paraffin block.

\section{STAINING FOR MAST CELLS}

Proteolysis $^{9}$ Trypsin (0.01\%), $0.05 \mathrm{mg}$ in $50 \mathrm{ml}$ calcium chloride, and $450 \mathrm{ml}$ distilled water buffered to pH 7.8 were used. Incubation times at $37^{\circ} \mathrm{C}$ were 10 , 20 , and 30 minutes.

Toluidine blue ${ }^{9}$ Sections from each levei were taken and stained with toluidine blue, 0.5 nitrogen hydrochloride ( $\mathrm{pH} 0.5$ ) for 30 minutes at 4,8 , and 16 hours and seven days.

IMMUNOHISTOCHEMICAL STAINING

Sections from each level were taken and the unlabelled antibody peroxidase method used ${ }^{10}$ after 30 minutes' incubation in $0.01 \%$ trypsin at $37^{\circ} \mathrm{C}{ }^{11}$

To bleach acid haematin sections were treated with 


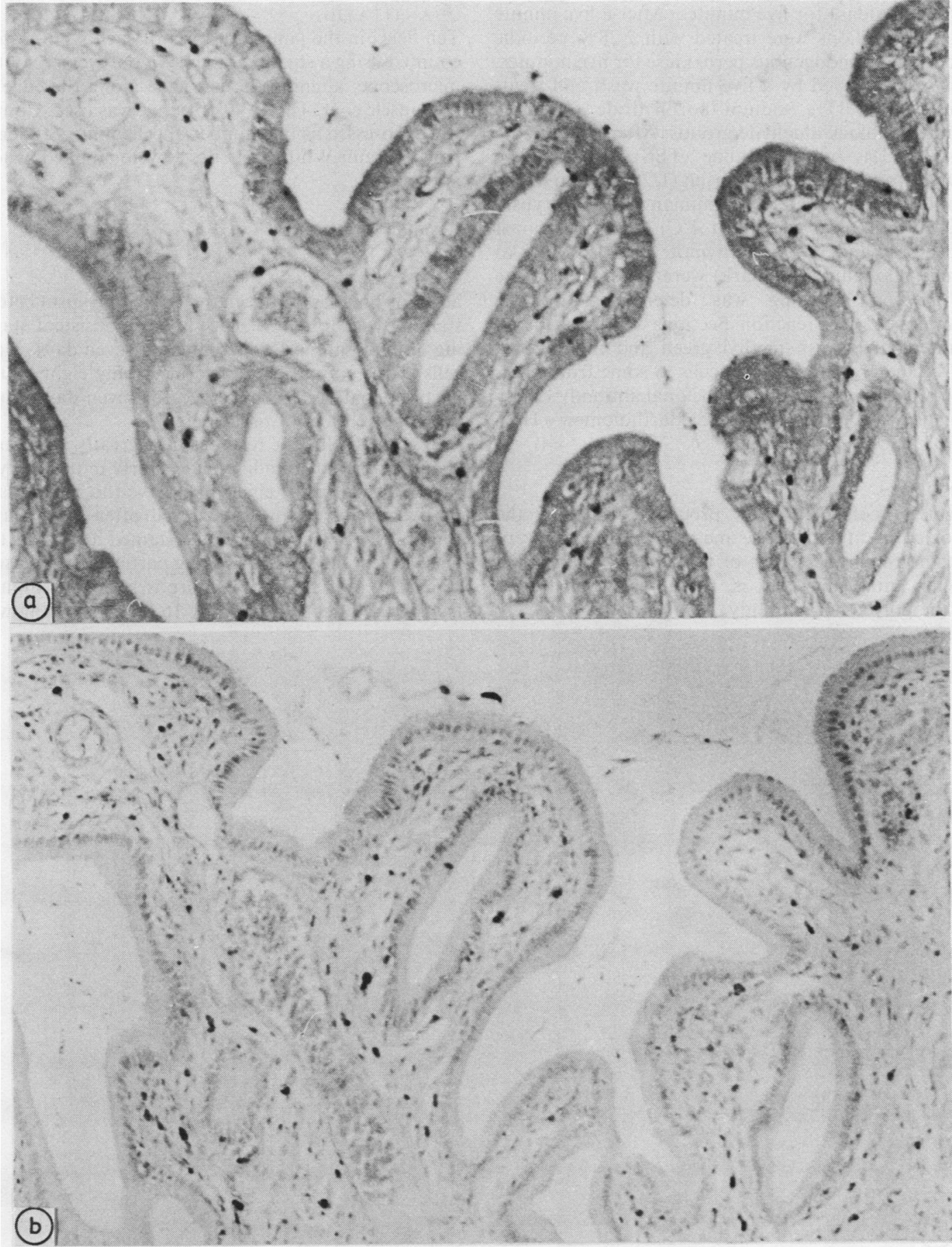

Fig la Paraffin section showing mast cells in gall bladder mucosa after trypsinisation and staining with toluidine blue. $\times 55$.

Fig lb Adjacent paraffin section to figure la to show $\alpha$-1-antitrypsin positive cells. $\times 55$. 
$7 \cdot 5 \%$ peroxidase for five minutes. After a five minute wash the sections were treated with $2 \cdot 28 \%$ periodic acid to block endogenous peroxidase for five minutes. This was followed by a five minute wash and treatment with $0.03 \%$ sodium borohydride for three minutes to block aldehyde groups. After a 30 minute wash in Tris buffered saline (TBS) sections were treated with normal swine serum (1/20 dilution for 30 minutes) and rabbit antihuman $\alpha$-1-antitrypsin $\left(1 / 2000\right.$ dilution overnight at $\left.4^{\circ} \mathrm{C}\right)$. Antisera against lysosomes and $\alpha$-1-anti-chymotrypsin (all Dako immunoglobulins, Denmark) were assessed. The site of antibody binding was determined by the diaminobenzidine reaction. Sections were washed and counterstained with methyl green and mounted in DPX. The presence of mast cells in some frozen sections was shown using a monoclonal antibody kindly provided by Dr E F Rimmer (St Bartholomew's Hospital).

\section{CONTROLS}

Negative controls were processed as for the peroxidase-antiperoxidase method with one exception: non-immune serum of the same species as the specific antiserum-that is, rabbit-was substituted for the polyclonal antibody.

\section{QUANTITATION}

Ten fields in the lamina propria of each section were counted using a square graticule in the eyepiece of the microscope, aligning the graticule along the edge of the muscle coat. The $\times 40$ objective was used. Counts were expressed as the number of cells $/ \mathrm{mm}^{2}$. Student's $t$ and Mann-Whitney $U$ tests were applied where appropriate.

\section{Results}

\section{MAST CELLS}

Sections that had not been treated with trypsin before staining with toluidine blue showed consistent staining of mucosal mast cells only after seven days. Mast cells in the subserosa stained after only eight hours. Sections that had been stained for seven days, however, showed loss of tissue detail.

Trypsin treatment resulted in a greatly shortened staining time for toluidine blue. Thirty minutes' trypsinisation was most efficient: it gave the same quantitative results as those achieved after seven days' staining. The mast cell granules stained dark blue, the mast cells in the subserosa being particularly intensely stained. For quantitative purposes the 30 minute trypsin treatment followed by 16 hours' staining was

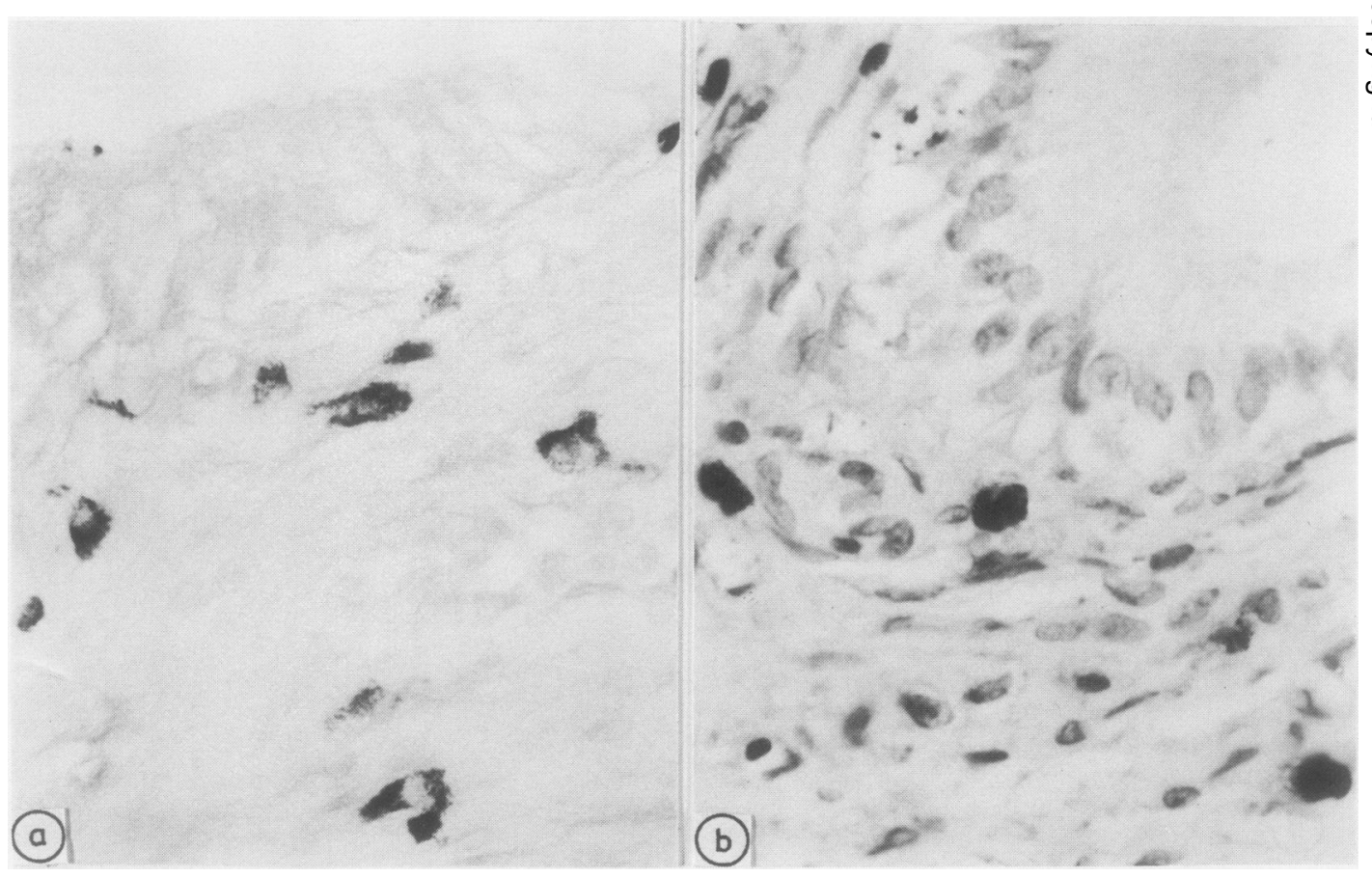

Fig 2a Mast cells in gall bladder mucosa stained by toluidine blue after trypsinisations. $\times 675$.

Fig 2b Alpha-1-antitrypsin positive cells in gall bladder mucosa. $\times 675$. 


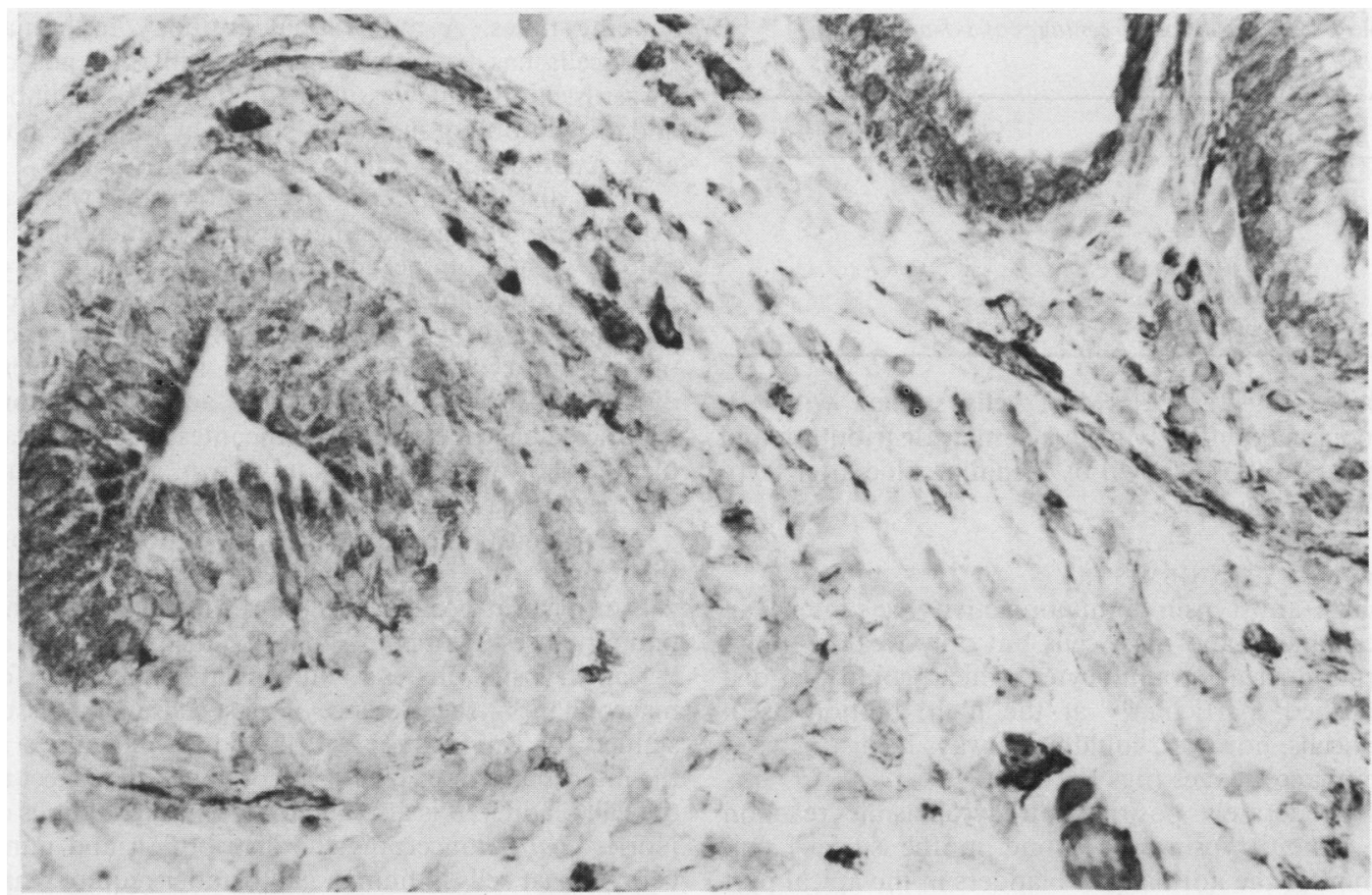

Fig 3 Frozen section of gall bladder showing mast cells, using monoclonal antibody directed against human mast cell granule contents. $\times 330$.

Table 1 Alpha-1-antitrypsin positive cells and mast cells $/ \mathrm{mm}^{2}$ in normal human gall bladder and chronic cholecystitis

\begin{tabular}{|c|c|c|c|}
\hline \multicolumn{2}{|l|}{ Alpha-I-antitrypsin } & \multicolumn{2}{|l|}{ Mast cells } \\
\hline Normal (cells/mm) & Cholecystitis (cells/mm) & Normal (cells/mm) & Cholecystitis (cells/mm) \\
\hline 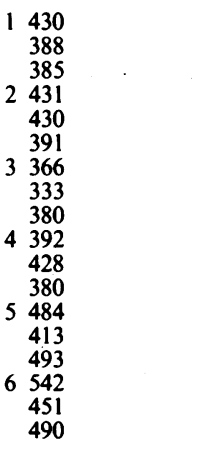 & $\begin{array}{r}7.360 \\
373 \\
352 \\
8123 \\
.185 \\
140 \\
9299 \\
251 \\
\\
268 \\
10 \quad 318 \\
327 \\
11297 \\
11221 \\
220 \\
119\end{array}$ & $\begin{array}{r}1352 \\
332 \\
308 \\
2280 \\
267 \\
\\
3280 \\
3246 \\
225 \\
4249 \\
4284 \\
305 \\
\\
5253 \\
5440 \\
427 \\
450 \\
6311 \\
288 \\
311 \\
\end{array}$ & $\begin{array}{rr}7 \quad 233 \\
269 \\
283 \\
8 \quad 89 \\
& 71 \\
& 77 \\
9 \quad 226 \\
239 \\
\\
10229 \\
10 \quad 209 \\
195 \\
11202 \\
11 & 139 \\
135 \\
123\end{array}$ \\
\hline Mean (SD) $422(50)$ & $260(77)$ & $310(65)$ & $181(70)$ \\
\hline$p=<0.001$ & & $p=<0.001$ & \\
\hline
\end{tabular}

Each number represents the mean of 10 counts of cells $/ \mathrm{mm}^{2}$ of mucosa. Each group of three means represents sections from three levels from one gall bladder. 
Table 2 Mast cells as percentages of $\alpha$-1-antitrypsin positive cells

\begin{tabular}{cl}
\hline Normal & Chronic cholecystitis \\
\hline $80 \cdot 2$ & 72.5 \\
66.0 & $53 \cdot 1$ \\
66.8 & 84.8 \\
$70 \cdot 2$ & 64.4 \\
94.7 & 62.2 \\
$62 \cdot 2$ & $67 \cdot 4(11 \cdot 9)$ \\
\hline
\end{tabular}

adopted (figs 1a, 2a). Mast cells stained with the monoclonal antibody gave a similar distribution and number to those shown by toluidine blue after trypsinisation (fig 3 ).

\section{IMMUNOCYTOCHEMISTRY}

Alpha-1-antitrypsin immunoreactivity was intense in macrophages and mast cells but only weak in polymorphonuclear granulocytes which could be distinguished, particularly at the high dilution used. Mast cells, however, could not always be distinguised from macrophages (figs $1 b, 2 b$ ).

A moderately positive intracytoplasmic reaction for $\alpha$-1-antitrypsin was found in the surface epithelium of the normal gall bladders in the apical part of the cells. A positive reaction was found in the surface epithelium in four of the five chronically inflamed gall bladders. Many pseudopyloric metaplastic cells were positive. The intensity of staining varied within individual specimens. No detectable staining was found in controls.

Immunoreactivity against lysozyme and $\alpha-1$-chymotrypsin gave less clear results than $\alpha-1$-antitrypsin and was not used again.

\section{QUANTITATION}

Tables 1 and 2 show the results of the quantitation. The overall number of cells $/ \mathrm{mm}^{2}$ at each level are shown for each gall bladder. Mast cells account for about $70 \%$ of the cells that stained for $\alpha$-1-antitrypsin.

There were considerably more mast cells and $\alpha$-1-antitrypsin positive cells in the minimal change gall bladder mucosae than in chronic cholecystitis.

\section{Discussion}

The problems entailed in showing the presence of mast cells in formaldehyde sections are well known. ${ }^{12}$ The improved staining of mucosal mast cells in formaldehyde fixed paraffin sections after treatment with trypsin has been described by Wingren and Enerbäck. ${ }^{9}$ Aldehyde fixation reversibly blocks the cationic dye binding of mucosal mast cell granules, ${ }^{13}$ which may be unmasked by trypsinisation or by long staining times. A monoclonal antibody to human mast cells has been developed but this depends on frozen section ${ }^{14}$ : it was used to confirm the number and distribution of mast cells shown by toluidine blue after trypsinisation of paraffin sections.

The distribution of $\alpha$-1-antitrypsin was as expected. ${ }^{15}$ The marker has also been identified in pyloric glands of the gastric antrum. ${ }^{16}$ Staining of pseudopyloric glands may reflect the local production of this inhibitor. The importance of local production of $\alpha$-1-antitrypsin is unknown: it may prevent digestion by proteolytic enzymes acting as a nonspecific defence mechanism in the intestine; in the gall bladder, however, its role is unknown, although gastric metaplasia has been described in this tissue. ${ }^{17}$

The quantitative results clearly show that more than half the cells included in a count of $\alpha$-1-antitrypsin-positive cells are mast cells. This finding raises two points: firstly, the suitability of $\alpha$-1-antitrypsin as a universal marker for macrophages - the presence of mast cells in any tissue stained for this marker will introduce difficulties in the interpretation of results; secondly, with respect to the gall bladder, it is also apparent that the findings of Norris $e a^{18}{ }^{18}$ concerning the distribution and numbers of mast cells in human gall bladder require reappraisal. Their results were expressed in terms of mast 8 cells per high power field, being 10 in the gall bladder mucosa. Rough calculations would bring this too $60-70 / \mathrm{mm}^{2}$. Janes and McDonald ${ }^{19}$ gave a value of $\rightleftharpoons$ 18 mast cells per field with $a \times 25$ objective lens using frozen sections. This would give values of about $45 / \mathrm{mm}^{2}$. Even allowing for a $30 \%$ shrinkage in paraffin sections, both sets of numbers are a considerable underestimate compared with those derived from the trypsin toluidine blue technique.

Mast cells are potentially important in the pathogenesis of gall bladder disease. Their granules contain a variety of preformed chemical mediators. ${ }^{20}$ Activation may be via the alternative or classical pathways of complement. C3a and C5a cause the release of histamine from both non-sensitised and sensitised mast cells in the absence of antibody. There is evidence of mast cell degranulation occurring in the gall bladder. ${ }^{1}$

As a tentative link with gall bladder disease histamine, via $\mathrm{H}_{2}$ receptors, induces the release of mucus from gastric glands and goblet cells in the respiratory tract. As mucus has been implicated in gallstone formation $^{21}$ it is possible that the release of histamine from mast cells may result in mucous hypersecretion in the gall bladder. Histamine via $\mathrm{H}_{1}$ receptors causes prostaglandins to be generated, and these have various biological activities including the induction of mucous secretion. Mast cells also contain several chemotactic factors such as histamine, neutrophil chemotactic factor, and eosinophil chemotactic fac- 
tors of anaphylaxis. The presence of this last group of substances may explain the occurrence of eosinophils in some gall bladders, ${ }^{22}$ although the pathological importance of eosinophils in the gall bladder largely remains obscure as it does elsewhere in the gastrointestinal tract. ${ }^{23}$

The numbers of mast cells found per $\mathrm{mm}^{2}$ of gall bladder mucosa are similar to those reported in normal small and large bowel. ${ }^{2425}$ Active mucosal inflammation in Crohn's disease is associated with a fall in mast cell number. ${ }^{25}$

We thank Mr G Coghill for his help with the tissues and Mrs Irene MacFarlane for her secretarial help.

\section{References}

1 Hopwood D, Kouroumalis E, Milne G, Bouchier IAD. Cholecystitis: a fine structural analysis. J Pathol 1980;130:1-13.

2 English M, Hopwood D. Lipid in the human gallbladder mucosa. A histochemical study by light and electron microscopy. $J$ Pathol 1985;146:333-6.

3 Monis B, Weinberg T. Cytochemical study of esterase activity of human neoplasms and stromal macrophages. Cancer 1961;14:369-77.

4 Lauder I, Aherne W, Stewart J, Sainsbury R. Macrophage infiltration of breast tumours: a prospective study. $J$ Clin Pathol 1977;30:563-8.

5 Klockars M, Reitamo S. Tissue distribution of lysozyme in man. J Histochem Cytochem 1975;23:932-40.

6 Travis J, Salveson S. Human plasma proteinase inhibitors. Ann Rev Biochem 1983;52:655-709.

7 Isaacson PG, Jones DB, Millward-Sadler GH, Judd MA, Payne S. $\alpha$-1-antitrypsin in human macrophages. J Clin Pathol 1981;34:982-90.

8 Benitez-Bribiesca L, Freyre R, De La Vega G. Immunofluorescent localisation of $\alpha$-1-antitrypsin in human mast cells. Life Sci 1973;13:631-8.

9 Wingren U, Enerbäck L. Mucosal mast cells of the rat intestine: a re-evaluation of fixation and staining properties with special reference to protein blocking and solubility of the granular glycosaminoglycan. Histochem $J$ 1983;15:571-82.

10 Sternberger LA, Hardy PH, Cuculis JJ, Meyer HG. The unlabeled antibody-enzyme method of immunohistochemistry. $J$ Histochem Cytochem 1970;18:315-33.
11 Mepham BL, Frater W, Mitchell BS. The use of proteolytic enzymes to improve immunoglobulin staining by the PAP technique. Histochem J 1979;11:345-57.

12 Huntley JF, Newlands GFT, Gibson S, Fergusson A, Miller HRP. Histochemical demonstration of chymotrypsin-like serine esterases in mucosal mast cells in four species including man. J Clin Pathol 1985;38:375-84.

13 Miller HRP, Walshaw R. Immune reactions in mucous membranes. Am J Pathol 1972;69:195-206.

14 Rimmer EF, Turberville C, Horton MA. Human mast cells detected by monoclonal antibodies. J Clin Pathol 1984;37: 1249-55.

15 Aroni K, Kittas C, Papadimitriou SS, Papacharalampous NX. An immunocytochemical study of the distribution of lysozyme $\alpha$-1-antitrypsin and $\alpha$-1-antichymotrypsin in the normal and pathological gallbladder. Virchows Arch (Pathol Anat) 1984;403:281-9.

16 Kittas C, Aroni K, Matani A, Papadimitriou CS. Immunocytochemical demonstration of $\alpha$-1-antitrypsin and $\alpha-1$-antichymotrypsin in human gastrointestinal tract. Hepatogastroenterology 1982;29:275-7.

17 Runge PM, Schwartz JN, Seigler HF, Woodward CH, Shelbourne JD. Gallbladder with ectopic gastric mucosa. Archives of Pathology 1978;102:209-11.

18 Norris HT, Zamcheck N, Gottlieb LS. The presence and distribution of mast cells in the human gastrointestinal tract at autopsy. Gastroenterol 1963;44:448-55.

19 Janes J, McDonald JR. Mast cells. Archives of Pathology 1948;45:622-34.

20 Metcalfe DD. Mast cell mediators with emphasis on intestinal mast cells. Ann Allergy 1984;53:563-75.

21 Lee SP, Carey MC, Lamont JT. Role of gallbladder mucous hypersecretion in the evolution of cholesterol gallstones. Studies in the Prairie dog. J Clin Invest 1981;67:1712-23.

22 Fox H, Mainwaring AR. Eosinophilic infiltration of the gallbladder. Gastroenterology 1972;63:1049-52.

23 Blackshaw AJ, Levison DAL. Eosinophilic infiltrates of the gastrointestinal tract. J Clin Pathol 1986;39:1-7.

24 Strobel S, Miller HRP, Ferguson A. Human intestinal mucosal mast cells: evaluation of fixation and staining techniques. $J$ Clin Pathol 1981;34:851-8.

25 Sanderson IR, Leung KBP, Pearce FL, Walker-Smith JA. Lamina propria mast cells in biopsies from children with Crohn's disease. J Clin Pathol 1986;29:279-83.

Requests for reprints to: Dr D Hopwood, Department of Pathology, Ninewells Hospital and Medical School, PO Box 120, Dundee DD1 9SY, Scotland. 